\begin{tabular}{|l|r|}
\hline \multicolumn{1}{|c|}{ S sciendo } & \begin{tabular}{c} 
NCF $\begin{array}{l}\text { Nordic } \\
\text { Concrete } \\
\text { Federation }\end{array}$ \\
\hline $\begin{array}{l}\text { C Article authors. This is an open access article distributed under } \\
\text { the Creative Commons Attribution-NonCommercial-NoDerivs } \\
\text { licens. (http://creaticecommons.org/licenses/by.nc-nd/3.0/). }\end{array}$
\end{tabular} \\
\hline & $\begin{array}{r}\text { ISSN online 2545-2819 } \\
\text { ISSN print } \quad \text { 0800-6377 }\end{array}$ \\
DOI: $10.2478 /$ ncr-2021-0009 & $\begin{array}{r}\text { Received: March 31, 2021 } \\
\text { Revision received: June 21, 2021 } \\
\text { Accepted: June 26, 2021 }\end{array}$ \\
\hline
\end{tabular}

\title{
A Comprehensive Summary of Available Legislation and Practices in Demolition and Construction \& Demolition Waste Management in the Arctic Region
}

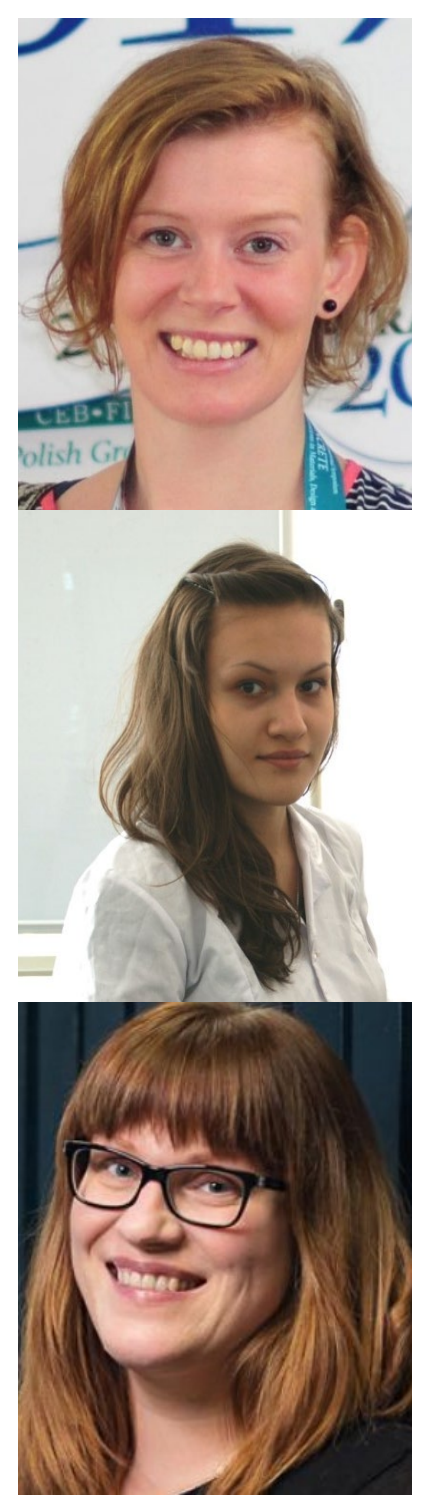

Iveta Nováková

Ph.D.

The Arctic University of Norway

Lodve Langes gata 2, NO-8514 Narvik

e-mail: iveta.novakova@uit.no

Tatiana Drozdyuk

M.Sc.

Northern (Arctic) Federal University named after M.V. Lomonosov Severnaya Dvina Emb. 17, RUS-163002 Arkhangelsk

e-mail: t.drozdyuk@narfu.ru

Katja Ohenoja

Dr., Doc., Senior research fellow

University of Oulu

Erkki Koiso-Kanttilan katu 5, FI-90570 Oulu

e-mail: katja.ohenoja@oulu.fi 


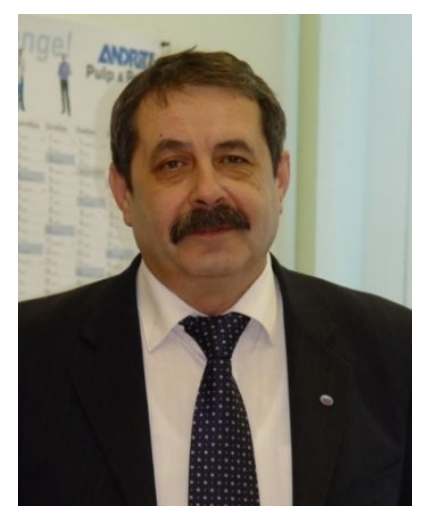

Arcady Ayzenshtadt

Prof., PhD., Doctor of Chemical Sciences

Northern (Arctic) Federal University named after M.V. Lomonosov

Severnaya Dvina Emb. 17, RUS-163002 Arkhangelsk

e-mail: a.isenshtadt@narfu.ru

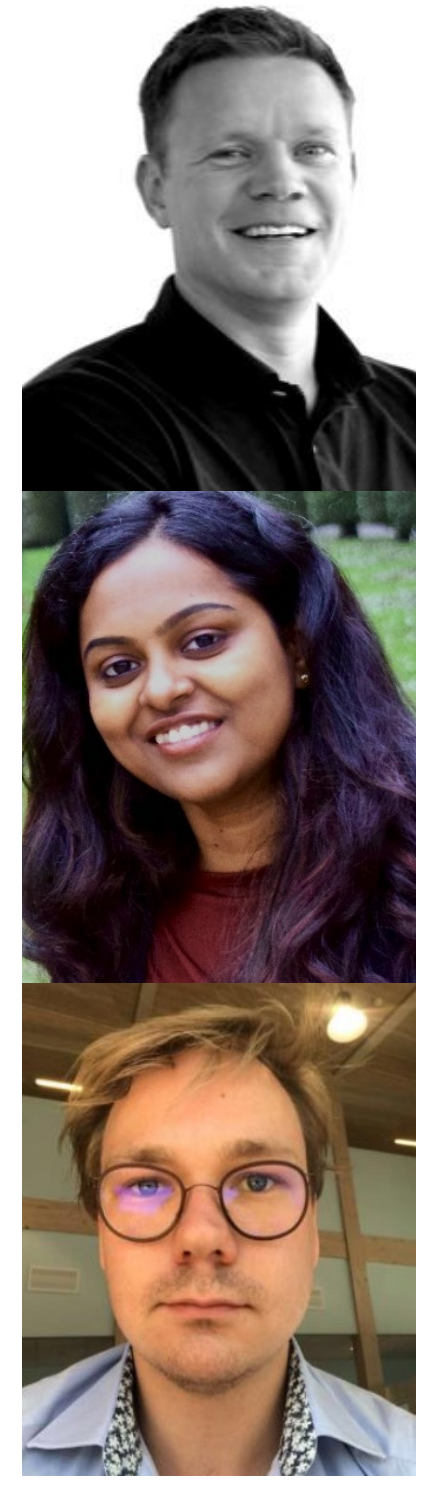

Bård Arntsen

M.Sc.

Sintef Narvik AS

Rombaksveien 47, NO-8517 Narvik

e-mail: baard@tek.norut.no

Priyadharshini Perumal

Dr., Postdoctoral researcher

University of Oulu

Erkki Koiso-Kanttilan katu 5, FI-90570 Oulu

e-mail: priyadharshini.perumal@oulu.fi

Martin Skjerve Dyvesveen

M.Sc.

The Arctic University of Norway

Lodve Langes gata 2, NO-8514 Narvik

e-mail: martin.s.dyvesveen@uit.no

\section{ABSTRACT}

The need for better natural resource use is currently increasingly recognised, and high emphasis is given to the circularity of building materials and the reduction of activities with negative environmental impact. Legislation, guidelines, and other documentation play an important role in improving demolition activities and construction and demolition waste (CDW) management. Good practices in CDW handling is not achievable without knowledge about CDW recovery techniques described in guidelines and other documents. 
Demolition activities in arctic regions could be more challenging due to harsh climate conditions, and therefore the cooperation between Russia, Norway and Finland was established to boost the uptake of good practices in demolition activities and CDW management. The main subject of this article is an overview of presently used demolition practices, CDW management, and verification of areas where practices with lower environmental impact and increase of material circularity could be utilised. Two fundamental documents, namely "EU Construction \& Demolition Waste Management Protocol" and "Guidelines for the waste audits before demolition and renovation works of buildings" [1, 2], were published by the European Union (EU) in 2019 and serve as a foundation for changes in demolition activities and CDW management in EU and adventitiously also in the Russian Federation and Norway.

Key words: Construction and demolition waste (CDW), legislation and guidelines, CDW management, recycling of concrete, selective demolition.

1.

\section{INTRODUCTION}

Construction and demolition waste is a mixture of different materials from demolition, renovation, construction activities and materials generated due to natural disasters [3 - 9]. The amount of CDW is rising along with the rising building activity worldwide, and it is well-known that the construction industry has a significant environmental impact [3, 10-13]. The building boom started in Europe first, then moved through America to Asia, and the main indicators could be steel, concrete and cement production, see Figure 1. Monitoring of produced concrete volume is rather difficult, and therefore, concrete production is based on data from cement production, which can be easily monitored in detail.
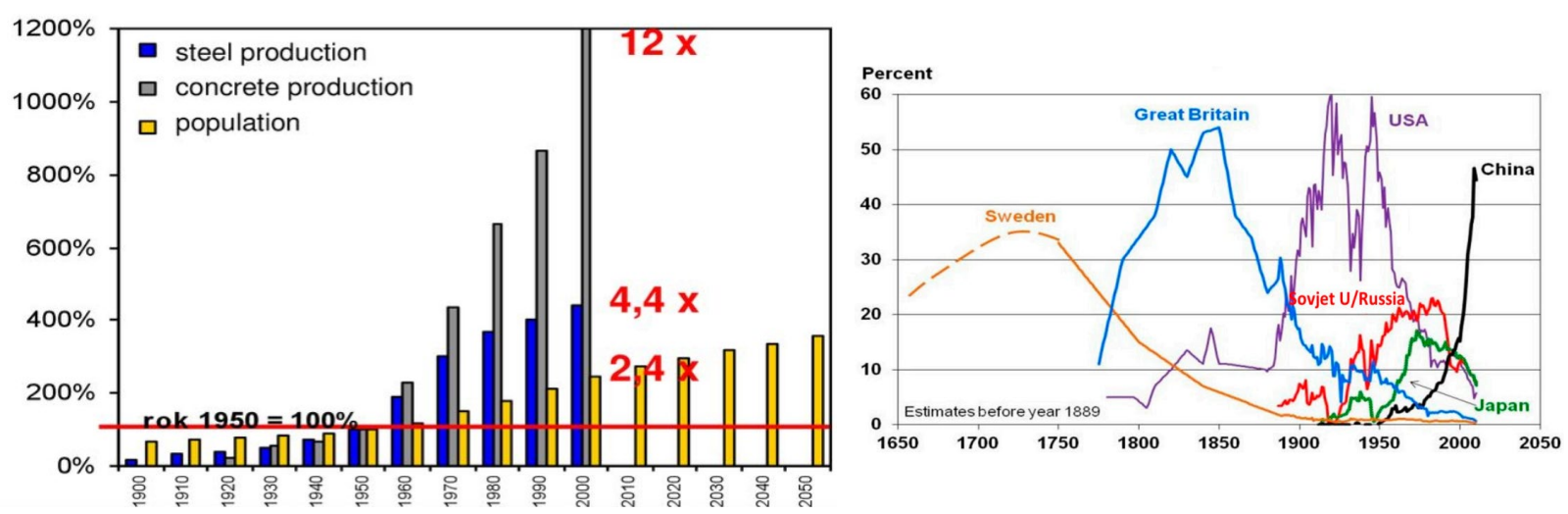

Figure 1 - (left) World production of concrete and steel between the years 1900 and 2050 [14]; (right) World steel production, historical data [15].

Building activities are predominantly taking place in the suburbs of big cities on empty areas or replacing old buildings, which are reaching their end of life. Production of CDW is higher in higher populated areas, and all this CDW must be transported to landfills located in city borders or further from the city centre in rural areas. At the other end of linear material flow, there is the raw material which is from rural areas brought to cities for building purposes. Integration of recovery, reuse, and recycling of CDW might be an exquisite solution for the reduction of material transportation on long distances, reduction of $\mathrm{CO}_{2}$ emissions and reduction of raw material resource consumption. Circular material flow and circular economy are nowadays highly discussed topics that have a positive impact on global warming and natural resource management. 
Globally, it is estimated that about $35 \%$ of the produced CDW is transported to landfills [3], but the actual percentage from individual countries varies significantly. There are multiple sources and databases providing and collecting data about CDW handling, and therefore variability of data from individual countries could be high. One of the reasons for high variability is the definition of CDW recovery, which can or cannot include backfilling. Backfilling is listed as one of the methods for the recovery of inert CDW [16]. Hopefully, it will soon be considered as bad practice and excluded from methods for CDW recovery. Examples of CDW handling in various countries are given in Table 1. The 28 European countries which in 2016 formed the EU produced approximately 374 million tonnes of CDW, excluding excavated soil [17, 18]. This amount accounts for 33\% of all produced waste in the EU [19] and making CDW the most significant waste stream in terms of mass. Due to the waste amount of CDW produced, the EU set a target of recover minimally $70 \%$ by weight of all non-hazardous CDW by 2020 in the EU Waste Framework Directive (2008/98/EC) [16], which most countries in the EU had already achieved in 2016 [17]. The numbers from 2020 have yet to be published [20, 21]. It is important to state that CDW recovery can be increased; European Environmental Agency estimates that $96 \%$ of all mineral (inert) material from CDW can be recycled [22, 23].

Table 1 - CDW management in selected countries.

\begin{tabular}{cccc}
\hline Country & Year & Recovered [\%] & Landfilled [\%] \\
\hline Finland* & 2011,2012 & $77^{[22]}$ & 23 \\
Norway & 2019 & $46^{[30]}$ & 54 \\
Russian Federation & 2019 & $5^{[65]}$ & 95 \\
USA & 2007 & 71 & $29^{[24,25]}$ \\
Brazil & 2012 & 60 & $40^{[26]}$ \\
Canada & 2012 & 73 & $27^{[26]}$ \\
Hong Kong & 2011 & 75 & $25^{[27]}$ \\
Hong Kong & 2014 & $93^{[3,28]}$ & 7 \\
China & 2014 & 5 & $95^{[3,22]}$ \\
South Korea, Japan & 2016 & $97^{[3]}$ & 3 \\
Denmark, Estonia, Netherlands, & 2017 & $80-90^{[3,29]}$ & $10-20$ \\
Germany and Great Britain & 2017 & $<15^{[3,29]}$ & $>85$ \\
Greece, Hungary, Portugal and Spain & 2017 &
\end{tabular}

*including soil, stones and dredging material

In China, approximately 1.13 billion tonnes of CDW were generated in 2014 [5] and accounted for $30 \%$ to $40 \%$ of the total waste mass [22]. Beijing alone accounts for 40 million tonnes of CDW annually, and about $5 \%$ of all CDW in China are recycled or reused $[3,22]$. Yuan $\mathrm{H}$ investigated barriers and countermeasures for managing CDW in Shenzhen [23] and found five drawbacks, which are:

- immature regulatory environment for managing CDW

- multiple government departments are separately involved in different CDW management processes, but no one takes the leading role

- lack of fundamental data in CDW

- insufficient attention is paid to waste management in construction projects

- $\mathrm{CDW}$ recycling factories trudge toward growth

And proposed five countermeasures which are: 
- enhancing the effectiveness of CDW regulations in reality

- collecting and releasing accurate and timely CDW amount

- enhancing CDW management

- promoting CDW recycling further

- implementing an effective waste disposal charging fee.

China does work on governmental policies concerning CDW, and they already have state-level regulation that encourages the use of recycled building materials in foundation work, road base and subgrade, etc. [5].

The main focus of this article is on Finland (FI), Norway (NO), Russian Federation (RUS) and partly on EU as FI is an EU member, and the other two countries have very close relations and cooperation with the EU. NO is a European Economic Area member and RUS has RussianEuropean Union relation. All three countries are aware of the necessity for a change in CDW management, and therefore established the project DeConcrete financed by Kolarctic - Cross Border Cooperation to accelerate the uptake of recovery, reuse, and recycling practices in the building industry.

FI: Generated 16 million tons of CDW, including soil, stones, and dredging material. This mass represents the amount, which was transported from the original location to the new location. The CDW, which was reused directly on-site or for roads between 2011 and 2012, is not considered. The composition of CDW is approximately 1.5-2 million tons of non-hazardous CDW from buildings, 14 million tonnes of soil and 0.15 million tons of hazardous CDW. The quantity of recovered CDW excluding soil, stones and dredging soil was approximately $77 \%$ by weight [22].

NO: Produces around 1.95 million tonnes CDW in 2019, and approximately 0.9 million tonnes were recycled, which stands for approximately $46 \%$ by weight [30]. In the coming years, it is expected that the amount of CDW will increase significantly [19], and the Norwegian Environment Agency requests new legislation on managing and handling CDW with the aim to promote recycling of CDW from the beginning of 2020 [31]. Documents such as "The Planning and Building Act", the "Pollution Control Act", the "Waste regulations" and "Product regulations" [32-35] have all been updated in 2020 to improve CDW handling and management.

RUS: Annually produces about 15-17 million tons of CDW, excluding soils, stones, and dredging material. Bricks and reinforced concrete debris represent about $60 \%$ of the total mass. The recycling rate covers about $5 \%$ of the total CDW. There is a CDW growth by approximately $25 \%$ due to high levels of building activities and demolition of structures, which have reached the end of life or do not comply with current urban requirements [65].

From all collected data about the handling of CDW, it is evident that there is room for improvement and increase of material circularity. One of the reasons for slow adaptation of good practice and full implementation of CDW recovery is insufficient legislation and lack of guidelines. The other reasons include market readiness and the economic benefits of CDW recovery for companies. The aim of the authors is to give a clear idea of existing documents for demolition action and CDW management in Finland, Norway, the Russian Federation and also, in brief, in the European Union. 


\section{DEMOLITION ACTION}

\section{Pre-demolition audit}

Performance of pre-demolition audit gives a greater possibility for recovery of building materials and integration of circular economy and material flow practices. It is the first step towards selective demolition from which can be obtained secondary raw materials for further processing, reusable elements, and recycled materials for direct use. The pre-demolition audit ensures traceability of material present in the object, which is about to be demolished and suggests further handling of CDW [1]. Before demolition or renovation of buildings and infrastructures, it is necessary to understand the type and amount of elements and materials that will be deconstructed and give recommendations or assessment for any further processing or viable recovery routes for such materials. The pre-demolition audits must also consider any relevant legislation if any material will be reused directly on-site or if there are any hazardous materials in the structure, and should have been performed at a minimum before applying to the demolition or renovation permit. The audit report should be revised in light of the final result of the construction, demolition, or refurbishment process [1].

FI: The pre-demolition audit is covered by building law $127 \S$ and $139 \S$, and demolition permit and notice are needed. Providers of pre-demolition audits (coursed for pre-demolition auditors) are mediated by building control or the authorities of the city or municipality who permits the demolition [36, 37]. Special own techniques for hazardous materials (like asbestos) removal, handling and delivery to the landfill are required. There are own landfill areas for hazardous waste. The most common building materials in Finland are wood, steel, brick, concrete and reinforced concrete.

NO: Legislation for pre-demolition assessment of constructions is covered in "NS 3420 Specification texts for building, construction and installations", "Building Research Design Guides" and "TEK17 - Building Technical Regulations" [38-40]. Those regulation are available and used more in the southern part of Norway. The Norwegian parliament and other departments in Norway adopt the audits and provide the necessary education. The auditor of construction is required to report about (i) who is performing the audit, (ii) the date of audit, (iii) when the construction was built and (iv) what purpose of use did it serve. Environmental mapping is obligatory before the demolition and consists of an inventory of materials present and hazardous materials, if any, their type, quantity, and location in the structure. Special techniques for hazardous materials removal, handling and delivery to the landfill are required $[39,40]$. The most common building materials in Norway are wood, concrete, reinforced concrete, and light-weight aggregate (LWA) blocks.

RUS: In the current regulatory and technical documentation of the Russian Federation, the concept of "demolition of a building" is absent. Dismantling of existing buildings and structures is considered a type of construction work; therefore, the procedure for obtaining a demolition permit is similar to obtaining a construction permit. For the building's demolition, it is necessary to develop design documentation, obtain permits and pass expert review. Project documentation for the demolition of buildings is developed based on a survey of the building's general condition (structure), including foundations, walls, columns, arches, and other structures. Details are described in Construction Standards and Regulations 12-04-2002. "Labour safety in construction" Part 2, construction operations [41]. It is necessary to make sure that the building is not a monument of architecture and culture. The most common building materials in Russia are calcium-silicate and clay bricks, stone, concrete, and reinforced concrete. 
It is crucial under demolition planning to have clear guidelines for CDW management to increase both the quality and quantity of CDW, which has the potential to be recovered. Specifying appropriate dismantling and demolition practices, identifying the CDW generation and ensuring workers' safety is essential for successful CDW management. Additionally, adequate documentation can be of great value when setting performance levels for several key factors in demolition and CDW management, such as demolition contractors, site-specific CDW management plans, environmental credentials, material and labour efficiency. The EU's Guideline for the pre-demolition audit, describes whom the management bureaucracy should include and their roles, see Figure 2 [1].

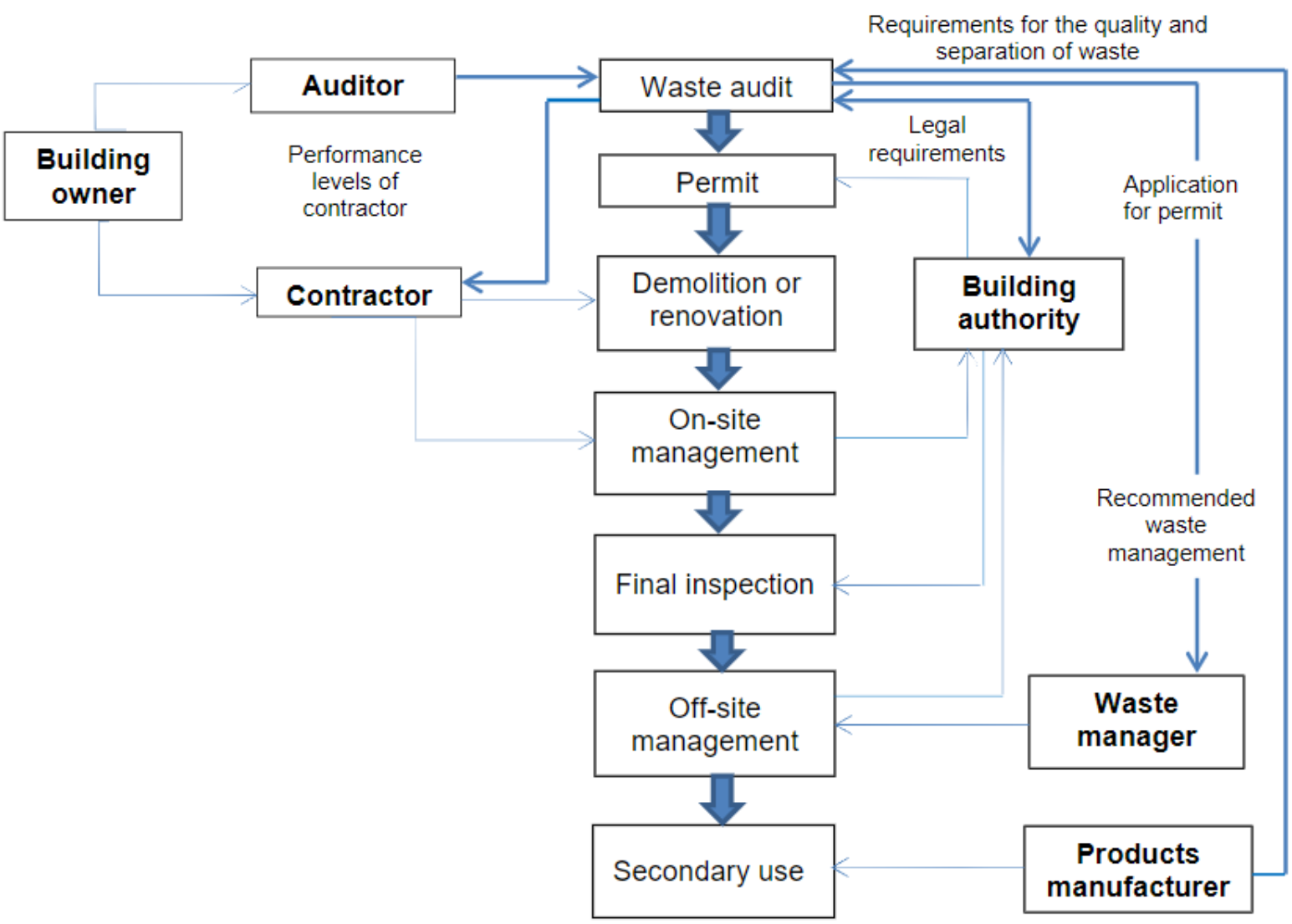

Figure 2 - EU's role of pre-demolition actors in the pre-demolition management process [1].

FI: The assessment for demolishing a structure is necessary and needs to follow several legislations concerning the construction, work safety, asbestos, waste and environment [42]. Samples are taken based on the auditors' experience, and if either asbestos or creosote contaminates the building, only specialised companies will have permission to do demolition work as asbestos demolition work. The amounts of asbestos, creosote, lead, PCB and microbes are measured (www.delete.fi). If it is uncertain that the building contains harmful compounds, the safety guidelines should be followed, for example, "Asbestos Demolition Work Guideline". The guideline describes the work conditions such as vacuum isolation of the building or special care in personal work safety. Different limits of contaminants for the inert, regular and hazardous wastes for Finish CDW are presented in Table 2. 
NO: In "Building Research Design Guides 700.804 Planning of demolition work" [19], the demolition management roles that need to be present are the developer, the permit applier, project manager, executor and third-party controller. Documentation describing environmental survey and remediation is necessary before demolition action, e.g., detecting contaminants and asbestos for remediation. These documentations should be according to Norwegian standards such as "NS 8141-2:2013 - Standard for vibration and shock" and "NS 9431:2011 - Classification of waste" $[43,44]$. There are different techniques for sampling materials, including core drilling, pigging, sawing, cutting, and carpet stripping, and a sample of each material type shall be taken. The sampling gives essential information about contaminants that are predominantly on the surface of walls and floors. Limits for the content of contaminants in CDW for Norway are seen in Table 2.

RUS: It is necessary to develop and coordinate a package of documents that include, in particular, the dismantling project for the demolition of dilapidated housing. In this regard, before starting a project for dismantling, it is necessary to survey the building in order to identify architectural and structural features for further safe dismantling. The entire survey complex is divided into Stage 1: Study of existing documentation, materials; Stage 2: Visual (preliminary) examination; Stage 3: Detailed instrumental examination and Stage 4: Survey Results. Limits for the content of contaminants in CDW for Russia are presented in Table 2.

Table 2 - Limits of selected contaminants in inert, regula,r or hazardous CDW for Russian Federation [45], Norway [46], Finland [47]

\begin{tabular}{cccccc}
\hline & $\begin{array}{c}\text { Russia } \\
\text { Inert CDW } \\
{[\mathrm{mg} / \mathrm{kg}]}\end{array}$ & $\begin{array}{c}\text { Norway } \\
\text { Inert CDW } \\
{[\mathrm{mg} / \mathrm{kg}]}\end{array}$ & $\begin{array}{c}\text { Inert CDW } \\
{[\mathrm{mg} / \mathrm{kg}]}\end{array}$ & $\begin{array}{c}\text { Finland } \\
\text { Regular CDW } \\
{[\mathrm{mg} / \mathrm{kg}]}\end{array}$ & $\begin{array}{c}\text { Hazardous CDW } \\
{[\mathrm{mg} / \mathrm{kg}]}\end{array}$ \\
\hline $\mathrm{As}$ & - & 15 & 0.1 & 0.4 & 6 \\
$\mathrm{Ba}$ & - & - & 7 & 30 & 100 \\
$\mathrm{Cd}$ & - & 1.5 & 0.03 & 0.6 & 3 \\
$\mathrm{Cr}$ & - & $\mathrm{Cr}^{\mathrm{III}}-100$ tot, & 0.2 & 4 & 25 \\
$\mathrm{Cu}$ & - & $\mathrm{Cr}^{\mathrm{VI}}-8$ & 0.9 & 25 & 50 \\
$\mathrm{Hg}$ & - & 100 & 0.003 & 0.05 & 0.5 \\
$\mathrm{Mo}$ & - & - & 0.3 & 5 & 20 \\
$\mathrm{Ni}$ & - & 75 & 0.2 & 5 & 20 \\
$\mathrm{~Pb}$ & - & 60 & 0.2 & 5 & 2 \\
$\mathrm{Sb}$ & - & - & 0.02 & 0.2 & 4 \\
$\mathrm{Se}$ & - & - & 0.06 & 0.3 & 90 \\
$\mathrm{Zn}$ & - & 200 & 2 & 25 & 17000 \\
$\mathrm{Chloride}$ & 1000 & - & 550 & 10000 & 200 \\
Fluoride & - & - & 4 & 60 & 25000 \\
Sulphate & $15000\left(\mathrm{SO}_{3}\right)$ & - & 560 & 10000 & 480 \\
DOC & - & - & 240 & 380 & 70000 \\
TDS & - & - & 2500 & 40000 & 200 \\
PCB & - & 0.01 & 1 & 1 & \\
PAH & - & $7-100$ & 200 & 200 & \\
\hline & & & & & 2 \\
\hline
\end{tabular}




\section{Demolition itself}

Each country has its national standards and guidelines concerning the demolition phase due to different demolition traditions and habits from the era before the EU. There are differences in acceptance of noise level and air pollutions, different topology where accessibility can be an issue, and different environment, health, and safety regulations. Therefore, the EU has not provided any common guidelines for demolition itself.

FI: "Land Use and Building Act 132/1999 - Legislation in force" - FINLEX [48] is the governing legislation on demolition and construction. When doing demolition work in Finland, selective demolition is the most common practice, whereas sorting demolition, renovation demolition, total demolition, blasting and burning are the most commonly used techniques. Under demolition work, the air's dust content outside the work zone cannot be higher than $0.05 \mathrm{mg} / \mathrm{m}^{3}$ of dust particles, and the noise level shall not exceed $55 \mathrm{~dB}$ [49]. Sorting of materials is recommended but is not compulsory. Therefore, the customer is required to specify if there will be any recycling or reuse of CDW.

NO: Has guidelines available on server "Building Research Design Guides" and for demolition purposes guidelines are provided "700.804 Planning of demolition work" [19] or " 241.070 Waste management in building cases - planning and documentation" [50]. Environmental mapping and decontamination during demolition are described in "Building management" 700.802 [51]. Selective demolition practices are not fully implemented in standard demolition practices, but Norway differentiates between non-load-bearing structures and load-bearing structures. Demolition of non-load bearing structures is performed either with hand tools or small machines adapted to interior work such as mini loaders and excavators, carpet strippers, motorised wheelbarrows, conveyor belts, crusher, and demolition robots. Load-bearing structures are usually carried out by mechanical knocking, pigging, sawing, wire sawing or core drilling. A combination of the methods is possible but depends on the prerequisites for the work. Reuse of elements such as doors and windows are often not practised due to their low value. During demolition work, the requirements for noise level and dust content in the air are enforced by the local municipalities. Depending on the time of day and location, the noise levels should not exceed 50-70 dB, and the level of air pollution shall not exceed $5 \mathrm{~g} / \mathrm{m}^{2}$. To ensure, that the level of air pollution and noise are in compliance with regulations, control and documentation are required. The noise and dust meters should be installed in specific locations on the construction site to monitor all activities [19].

RUS: Demolition or dismantling of an object should be performed in the reverse order of construction, i.e., from top to bottom, by floors, by sections, by spans according to construction regulation "SP 325.1325800.2017 Buildings and construction - rules for the production of demolition and recycling" [52]. There are two methods for dismantling buildings in Russia, demolition, and disassembly. Disassembly is mainly used in dense urban areas while demolition is used in the countryside, the method has its differences where dismantling is differentiated into three categories described in Figure 3. At the main stage of the dismantling of various buildings, manual, semi-mechanised, mechanised, and explosive dismantling methods are used.

In some cases, selective demolition is used, but the most common method is a combination of the previously stated techniques for dismantling or demolishing. The practice of reusing whole elements, such as windows, roof beams or roofing is common. During demolition or dismantling, dust content outside of the work zone shall not exceed $0.3 \mathrm{mg} / \mathrm{m}^{3}$ [53]. Noise level assessment of the work zone is carried out following construction and regulations 51.13330.2011 "Protection 
against noise" [53], and for residential areas, the noise level in the daytime should not exceed 70 dB.

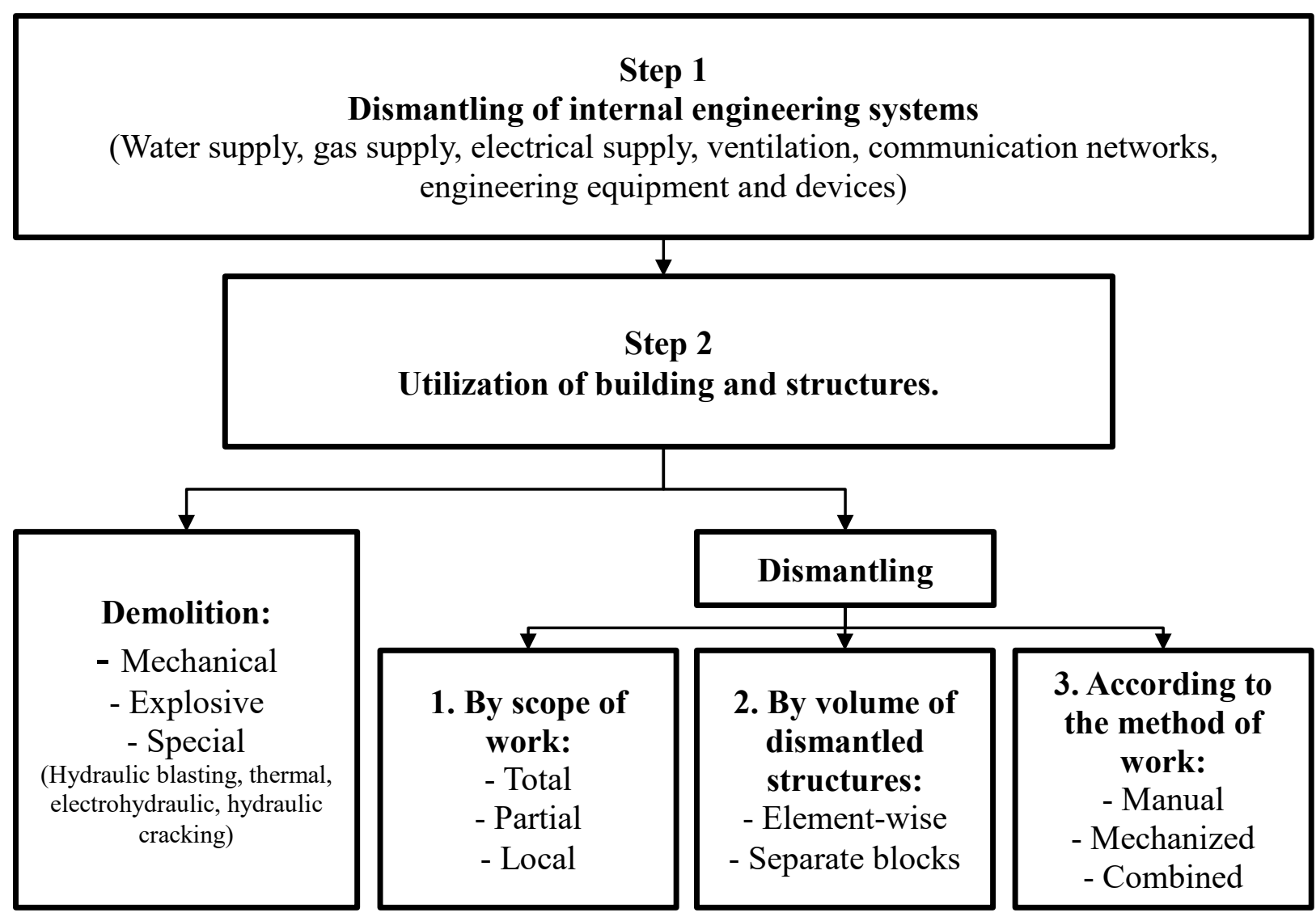

Figure 3 - RUS: Dismantling of the object (Organization Standard NOSTROY 2.33.53-2011) liquidation of the building (structure) by dismantling prefabricated and collapsing monolithic structures with the preliminary dismantling of technical systems and decoration elements [54].

\section{CONSTRUCTION AND DEMOLITION WASTE MANAGEMENT}

While the pre-demolition audit focuses on the product, a logistic waste management plan focuses on whether it is possible to reused or recycle any material from construction, renovation or demolition. A good waste management plan contains information about demolition phases, the contractor, materials to be collected, transportation for each material, recycling, reuse, or final treatment of each material. The plan should also address environmental, health and safety issues, environmental impact limitations, and how the inert, contaminated, and hazardous waste are managed [2]. The EU's CDW management is illustrated in Figure 4 where there are three stages of management and three stages of a liable party [55]. 


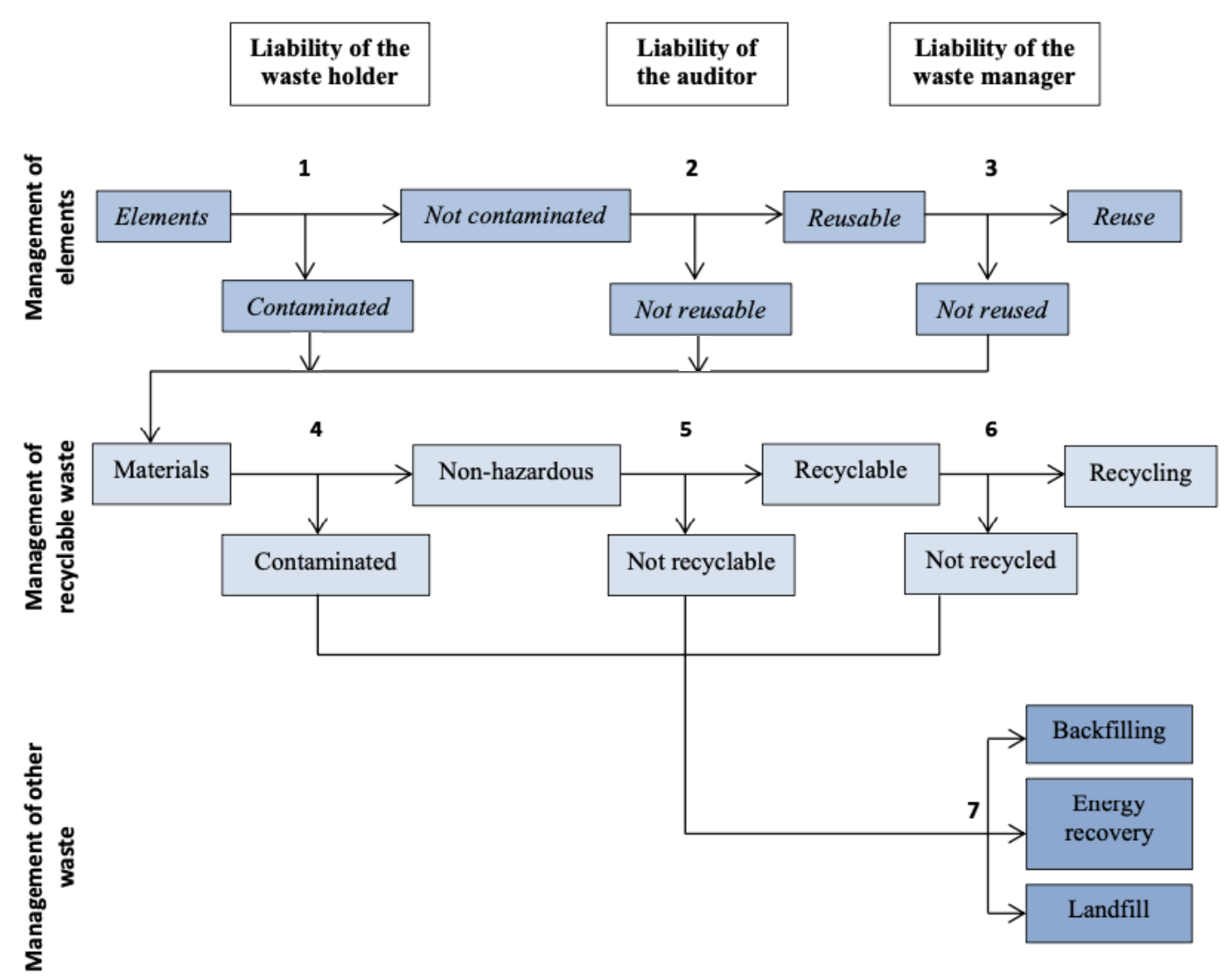

Figure 4 - Decision-making process in the formulation of the inventory and management recommendations [55].

\section{1}

\section{Handling of CDW}

There is several theories or techniques which could be applied to waste management in all fields and industries. The Life Cycle Assessment (LCA), cradle-to-grave (linear model) or cradle-tocradle (circular model) analyses are suitable for the description of CDW handling. If the life cycle of an existing construction is described as cradle-to-grave model, "cradle" represents building materials used for the structure, and the "grave" represents demolition and disposal of CDW in a landfill. When recovery, reuse, or recycling of CDW is considered, it is referred to as cradle-tocradle or closed-loop models [56]. C. Broadbent [57] studied the benefit of a cradle-to-cradle methodology in steel production. It was found that every $1 \mathrm{~kg}$ of steel scrap that is recycled at the end of a product's life will reduce environmental emissions by $1.5 \mathrm{~kg} \mathrm{CO}$-eqv. (73\%), reduce energy consumption by $13.4 \mathrm{MJ}(64 \%)$ and reduce material depletion with $1.4 \mathrm{~kg}(90 \%)$ iron ore, compared to $100 \%$ primary production. The cradle-to-cradle methodology demonstrates a significant reduction of emission firstly by lowered extraction of raw materials and secondly by removing occupancy of space at the landfill. C. Knoeri et al. [58] compared the LCA of recycled concrete (RC) against conventual conventional concrete (CC) for structural application in accordance with Swiss standards. The authors stated that the environmental benefits of high-grade $\mathrm{RC}$ have been doubtful since cement content is the main contributor to the global warming potential of concrete. Another study compared a linear model of concrete waste handling with two 
circular models, where the RCA was used either as road base material or in concrete production with a replacement ratio of $50 \%$ of natural aggregates by RCA, see Figure 5 . The scenario analysis was applied on a construction project in Iskandar, Malaysia, and a reduction of overall environmental impact due to reuse and recycling was concluded [59].
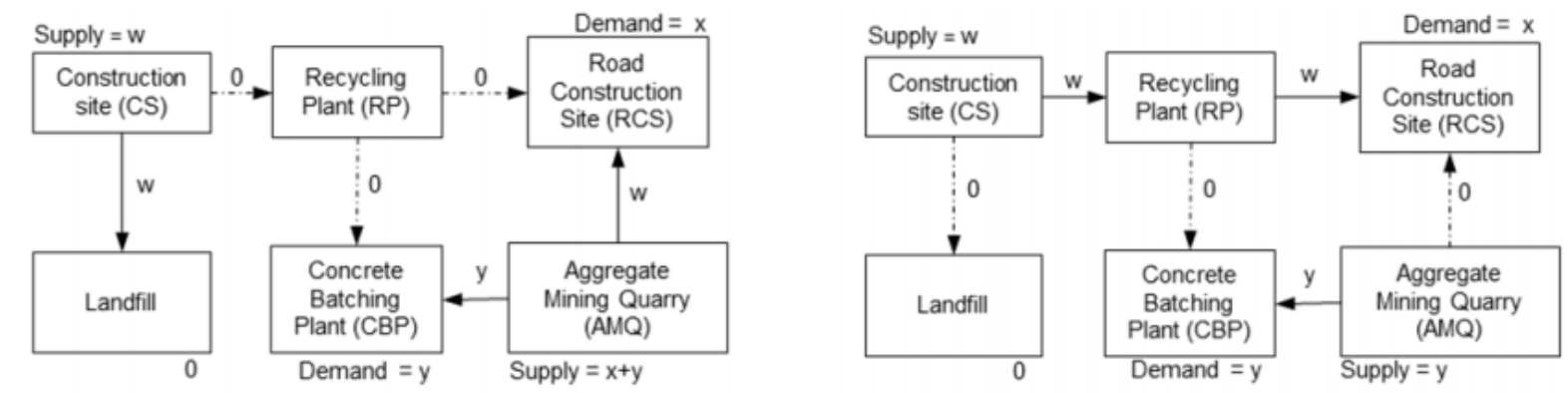

Figure 5 - (left) System boundary for scenario 1 - landfilling, (right) System boundary for scenario 2 where concrete waste is recycled as road base material [59].

The Waste Framework Directive states that EU member countries shall take measures to promote up-cycling, in other words, a gain of material with the highest possible preserved quality. The EU member countries shall also set up separate recycling centres where known methods of recycling can be practised. These materials can be paper, metal, plastic, and glass [16]. To enforce such directives, the EU requires all member states to report the present status of CDW recovery level to the commission.

If $70 \%$ recovery level by 2020 is not met (CDW recovery level set by EU), member states should report the reason and the action which the member state intends to take to achieve the set targets [16]. The process of recycling of CDW requires significant space and the feasibility is highest in densely populated and urbanised areas. Public authorities and municipalities need to have several roles in defining a proper recycling logistic based on location and overcoming "Not in my Backyard" mentality for more local recycling centers in urban areas [2].

When handling hazardous CDW the establishments and undertakings which collect or transport hazardous materials shall keep a chronological record of the quantity, nature and origin of the material. The records of hazardous waste shall be stored in a database for at least three years, and data about transport must be kept for at least 12 months [16].

FI: Follow the "Waste Framework Directive" 2008/98/EC [16] as well as directive 1999/31/EC "Landfill of waste" [60]. In total $80 \%$ of CDW processed and is utilised via Finnish earth construction act 843/2017 "Government Decree on the Recovery of Certain Wastes in Earth Construction" [47] and standard SFS-EN 13242 [49]. The rest of the CDW is landfilled for a price of 70 Euro per ton $(€ / \mathrm{t})$ in 2020 . There are over 200 landfills around Finland.

NO: Has national guidelines for handling the CDW, mostly from Building Research Design Guides and Environmental Agency [39, 61]. Most of the CDW was landfilled until the end of 2019. In 2018, approximately $0.5 \%$ of concrete and LWA-brick waste were recycled. Whereas $63 \%$ were disposed at landfills, and 34\% was backfilled [61]. Now there is a trend of backfilling and direct utilisation in the construction industry. Inert CDW such as crushed concrete and LWAbricks are used in road construction, noise barriers, parking lots, and earthworks, while lightly contaminated CDW is evaluated individually in the CDW centres. If the contaminated CDW is reused, the contamination limits must not be exceeded. Norwegian landfills classify CDW into 
three categories, namely inert waste, contaminated waste, and hazardous waste. There are 64 landfills in Norway, but only two landfills are for hazardous waste. Furthermore, there are two recycling centres for soil, and a recycling centre for concrete and brick debris is scheduled to be built in 2021 by AF Decom.

RUS: Currently, there is no unified concept of construction and demolition waste, as well as the established term for such waste, although Russia has 243 recycling centres that process CDW in recycled aggregates (RA) and the price for income CDW is approx. $4 € / t$ (270 rub/t). Landfilling of hazard waste costs from 9.5 to $66 € /$ t. Unfortunately, the fourth hazard class (practically nonhazardous) has a price of $0.6 € / t$, which exposes the disadvantage of recycling CDW. The Russian Federation's legislation on waste management is primarily aimed at improving the ecology and environmental protection, despite that there is no precise regulation of the waste recycling system.

\section{2}

\section{Utilisation of secondary raw materials (SRM) produced from CDW}

To complete the circular approach, the usability of SRM shall be provided and allowed. Conditions for the use of SRM are sometimes too high and hardly reachable, which has a significant impact on the uptake of circular material flow. Recognition of places, where SRM can be applied is crucial and can lead to the establishment of reuse and recycling of CDW as an indispensable part of the building industry.

FI: The Earth Construction Act governs the utilisation of crushed concrete waste [47]. Crushed concrete can be used as a filling material for roads, fields, and floor structures of industrial or storage buildings if the solubility of harmful elements is not exceeded. The CDW layer thickness for these is $\leq 1,5 \mathrm{~m}$. Some Finnish companies have commercialised crushed concrete (e.g. Rudus and Delete), but it is used only in earth construction, not concrete. All countries from the EU follow the EN 206 standard, which allows a certain percentage of RCA to replace natural aggregates by, yet it is not common in the practice of concrete producers as the certification of concrete mixes might be more complex.

NO: Products in the construction industry certified and marked with EU-flower or that has been evaluated by ECO-product with a score of 6 or higher in "waste" and a green or white mark on hazardous substances, is advised in recycling. If the product has not been certified, it is up to the contractor to obtain information and decide if it is recyclable [40]. Recycled aggregate has been included in all Norwegian standards and legislation which mentions natural aggregate from road construction and concrete to railway ballast. In NS-EN 12620 [62], recycled aggregate is defined by two types of qualities, AN and BN. AN has a dry density of more than $2000 \mathrm{~kg} / \mathrm{m}^{3}$, water absorption of less than $10 \%$ and can only include less than $1 \%$ of non-mineral contaminants or glass. Type BN has a dry density of more than $1800 \mathrm{~kg} / \mathrm{m}^{3}$, water absorption of less than $20 \%$ and cannot include more than $5 \%$ by volume of non-mineral contaminants or glass [63]. Further, NSEN 206 specifies conditions for replacing natural aggregate with recycled aggregate based on the concrete strength and durability, given in Table 3 [63]. 
Table 3 - Norwegian conditions for the use of RA fraction [63].

\begin{tabular}{ccc}
\hline $\begin{array}{c}\text { Conditions for Recycled Aggregate } \\
\text { Fraction }\end{array}$ & $\leq \mathrm{C} 25 / 30-\mathrm{X} 0$ & $\leq \mathrm{C} 45 / 55-\mathrm{X} 0, \mathrm{XC} 1, \mathrm{XC} 2$, \\
$\mathrm{XC} 3, \mathrm{XC} 4, \mathrm{XF} 1$
\end{tabular}

RUS: Processed CDW can be used as aggregates for various purposes, such as material for the foundations of highways, the foundations of runways and airport aprons, roadsides, components for ready-made mixtures utilised in reclamation, landscaping, and earthwork. All mentioned applications are regulated by the Interstate standard 32495 [45].

Processing of disposed reinforced concrete products from demolition or dismantling of buildings are also used for the manufacture of concrete mixtures and mortars. Russian State Standard 26633 [64] states that the use of crushed RA in concrete mixtures in the production of concrete and reinforced concrete structures with a strength of 5-20 MPa and a strength of 20-30 MPa (when mixed with natural aggregates) is allowed only after testing to confirm the possibility of obtaining concrete with standardised quality indicators.

Table 4 - Product price [€/t]

\begin{tabular}{cccc}
\hline & Russia & Norway & Finland \\
\hline Natural aggregates (NA) & 7.5 & $10-14.5$ & 10 \\
Recycled aggregates (RA) & 3.6 & - & 22.2 \\
\hline
\end{tabular}

\section{4.}

\section{CONCLUSIONS}

The following conclusions were drawn from an extensive review of document and discussions with demolition and CDW management industry representatives:

FI: Shows evident dedication toward recycling where they have already completed the EU's goal of recycling $70 \% \mathrm{CDW}$ by weight. In total, $80 \%$ of crushed concrete waste is utilised in Finland. Only contaminated CDW is going to landfills. CDW is used in roads, fields, and floor structures of industrial or storage buildings if harmful elements' solubility is not exceeded.

NO: There are many different standards and regulations regarding demolition and CDW handling, but parts about selective demolition, recovery, reuse, and recycling of CDW are missing. Predemolition audit and more precise plans for demolition are being discussed, and new regulations and guidelines introduced. Companies conducting demolitions are starting to take up selective demolition practises, increasing material circularity and implementing the circular economy. Finally, a change of legislation, significantly adjusting the limit of Chrome VI from $2 \mathrm{mg} / \mathrm{kg}$ to 8 $\mathrm{mg} / \mathrm{kg}$ will establish an entirely new value chain and marketplace with recycled aggregates produced from inert CDW. Norway produces annually 1,5-2 million tons of CDW, only $42 \%$ by weight is recovered, and most of the CDW goes straight to one of the 64 landfills. There is a lot to improve if Norway wishes to follow the EU's guidelines toward pre-demolition auditing and CDW handling. In the year 2020, Norway updated most of their legislations regarding demolition and CDW handling. 
RUS: Russia does not have a unified concept of construction and demolition waste yet, but the current legislation in waste management focuses on improving the ecology and environmental protection. Even though there is no precise regulation of the waste recycling system, Russia recycles and has sub-legislation concerning demolition and disposal of construction waste and the pre-demolition audit. With annual produce of 15-17 million tons of CDW and 5\% recycling rate with 243 recycling centres, there is room for much improvement if Russia wishes to follow the European Unions' goal of 70\% recovery rate by weight recovery of non-hazardous CDW.

\section{ACKNOWLEDGEMENTS}

The outcome has been achieved with the financial support from Kolarctic project no. KO4068 "DeConcrete: Eco-efficient Arctic Technologies Cooperation". Special thanks to bachelor students Aleksander Karlsen and Hermod Werner Kristiansen from UiT.

\section{REFERENCES}

1. European Commission "Guidelines for the waste audits before demolition and renovation works of buildings". 2018.

2. European Commission, The Directorate-General for Environment "EU Construction \& Demolition Waste Management Protocol". Official Journal of the European Union. 2016. No. June, p. 1-22. DOI 10.3390/su11133638.

3. Menegaki M \& Damigos D: "A review on current situation and challenges of construction and demolition waste management". Current Opinion in Green and Sustainable Chemistry, Vol 13, 2018, pp. 8-15.

4. Ibrahim M \& Ibrahim M: "Estimating the sustainability returns of recycling construction waste from building projects”. Sustainable Cities and Society, Vol 23, 2016, pp. 78-93.

5. Jin Ruoyo J, Li B, Zhou T, Wanatowski D \& Piroozfar P: "An empirical study of perceptions toward construction and demolition waste recycling and reuse in China". Resources, Conservation and Recycling, Vol 126, 2017, pp. 86-98.

6. Tucker R \& Park J: "Overcoming barriers to the reuse of construction waste material in Australia: a review of the literature". International Journal of Construction Management, Vol 17, No 3, 2017, pp. 228-237.

7. Umar U, Shafiq N, Malakahmad A, Nuruddin M \& Khamidi M: "A review on adaptation of novel techniques in construction waste management and policy". Journal of Material Cycles and Waste Management, Vol 19, No 2, 2017, pp. 1361-1373.

8. Domingo N \& Luo H: "Canterbury earthquake construction and demolition waste management: issues and improvement suggestions". Internation journal of disaster risk reduction, Vol 22, 2017, pp. 130-138.

9. Faleschini F, Zanini M, Hofer L, Zampieri P \& Pellegrino C: "Sustainable management of demolition waste in post-quake recovery processes: The Italian experience". International journal of disaster risk reduction, Vol 24, 2017, pp. 172-182.

10. Abarca-Guerrero L, Maas G \& Twillert H: "Barriers and Motivations for Construction Waste Reduction Practices in Costa Rica”. Resources, Vol 6, No 4, 2017, pp. 69.

11. Magalhães R, Danilevicz Â \& Saurin T: "Reducing construction waste: A study of urban infrastructure projects". Waste Management, Vol 67, 2017, pp. 265-277. 
12. Ding Z, Zhu M, Tam V, Yi G \& Tran C: "A system dynamics-based environmental benefit assessment model of construction waste reduction management at the design and construction stages". Journal of cleaner production, Vol 176, 2018, pp. 676-692.

13. Ajayi S, Oyedele L, Bilal M, Akinade O, Alaka H \& Owolabi H: "Critical management practices influencing on-site waste minimisation in construction projects". Waste Management, Vol 59, 2017, pp. 330-339.

14. Hajek, P. C3 Design of sustainable construction. [online]. [Accessed 23 February 2021] Available from: https://slideplayer.com/slide/15831861/.

15. Swedish Iron and Steel Makers Association; Jernkontoret: Stockholm, Sweden, 2019.

16. European Commission: "Directive 2008/98/EC of the European Parliament and of the Council of 19 November 2008 on waste and repealing certain Directives". Official Journal of the European Union, Vol 312, No 3, 2008.

17. Thanwadee C: "Investigation of factors affecting a construction waste recycling decision". Civil Engineering and Environmental Systems, Vol 33, No 3, 2016, pp. 214-226.

18. European Environment Agency: "Construction and demolition waste: challenges and opportunities in a circular economy". Jan 2020.

19. SINTEF Byggforsk: "700.804" , "Planlegging av rivearbeider". Oslo, Norway, 2011 (In Nowegian).

20. European Environment Agency: "The case for increasing recycling: Estimating the potential for recycling in Europe”. Jun 2020.

21. European Environment Agency: "The European environment - state and outlook 2020". Dec 2019.

22. Huang B, Wang X, Kua H, Geng Y, Bleischwitz R \& Ren J: "Construction and demolition waste management in China through the $3 \mathrm{R}$ principle". Resources, Conservation and Recycling, Vol 129, 2018, pp. 36-44.

23. Yuan H: "Barriers and countermeasures for managing construction and demolition waste: A case of Shenzhen in China". Journal of Cleaner Production, Vol 157, 2017, pp. 84-93.

24. Ajayi, Saheed O \& Lukumon O: "Policy imperatives for diverting construction waste from landfill: Experts' recommendations for UK policy expansion". Journal of Cleaner Production, Vol 147, 2017, pp. 57-65.

25. Ann T, Poon C, Wong A, Yip R \& Jaillon L: "Impact of Construction Waste Disposal Charging Scheme on Work Practices at Construction Sites in Hong Kong". Waste Management, Vol 33, No 1, 2013, pp. 138-146.

26. Oyedele L, Ajayi S \& Kadiri K: "Use of recycled products in UK construction industry: An empirical investigation into critical impediments and strategies for improvement". Resources, Conservation and Recycling, Vol93, 2014, pp. 23-31.

27. Lu W \& Tam V: "Construction waste management policies and their effectiveness in Hong Kong: A Longitudinal review". Renewable and sustainable energy reviews, Vol 23, 2013, pp. 214-223.

28. Hossain, Uzzal M, Wu Z \& Poon C: "Comparative environmental evaluation of construction waste management through different waste sorting systems in Hong Kong”. Waste Management, Vol 69, 2017, pp. 325-335.

29. Ulubeyli S, Kazaz A \& Arslan V: "Construction and demolition waste recycling plants revisited: management issues". Procedia Engineering, Vol 172, 2017, pp. 1190-1197.

30. Statisk sentralbyrå, Avfall fra byggeaktivitet. [Online]. [Accessed 23 February 2021]. Available from: (In Norwegian).

31. Miljødirektoratet, Avfallsplan 2020-2025. [online]. [Accessed 22 February 2021]. Available from: https://www.regjeringen.no/contentassets/c6a9a384d90c4af18bfd8458f3167708/avfallspla n-2020-2025.pdf (In Norwegian). 
32. Lovdata, Lov om planlegging og byggesaksbehandling (plan- og bygningsloven). [Online]. [Accessed 23 February 2021]. Available from: https://lovdata.no/dokument/NL/lov/200806-27-71/*\#\&\#x2a (In Norwegian).

33. Lovdata, Lov om vern mot forurensinger og om avfall (Forurensningsloven). [Online]. [Accessed 23 February 2021]. Available from: https://lovdata.no/dokument/NL/lov/198103-13-6 (In Norwegian).

34. Lovdata, Forskrift om gjenvinning og behandling av avfall (avfallsforskriften). [Online]. [Accessed 23 February 2021]. Available from: https://lovdata.no/dokument/SF/forskrift/2004-06-01-930/*\#\&\#x2a; (In Norwegian).

35. Lovdata, Forskrift om begrensning I bruk av helse- og miljøfarlige kjemikalier og andre produkter (produktforskriften). [Online]. [Accessed 23 February 2021]. Available from: https://lovdata.no/dokument/SF/forskrift/2004-06-01-922 (In Norwegian)

36. Iacoboaea $\mathrm{C}$, Aldea M \& Petrescu F "Construction and demolition waste-a challenge for the construction and demolition waste - a challenge for the European Union? Theoretical and empirical researches in urban management". 2019.

37. Haku - Suomi.fi. [online]. [Accessed 23 February 2020]. Available from: https://www.suomi.fi/haku?p=0\&q=Purkamisluvat\&sl=false (In Finish).

38. Norwegian Standard: "NS 3459:2012", "Exchange of data for specifications, price information and settlements in building and civil engineering works". Norway, 2012, 56 pp. (In Norwegian).

39. Byggforskerserien [Online]. [accessed 16.02.2021]. Available from: https://www.byggforsk.no/byggforskserien (In Norwegian).

40. Directory for Buildingquality: "TEK17" [online]. [Accessed 11.02.2021]. Available from: https://dibk.no/regelverk/byggteknisk-forskrift-tek17/ (In Norwegian).

41. Nation Standards of Russia: "Construction Standards and Regulations 12-04-2002", "Safty in construction. Part 2. Construction works". Moscow, Russia, 2002, 36 pp.

42. Lehtonen K "Purkutyöt - opas tekijöille ja teettäjille". Ministry of the environment publications [online]. 2019. [Accessed 23 February 2020]. Available from: https://julkaisut.valtioneuvosto.fi/bitstream/handle/10024/161884/YM_2019_29.pdf?sequ ence $=4 \&$ isAllowed $=$ y\#page $=5 \&$ zoom $=$ auto,-82,754 (In Finish).

43. Norwegian Standard: "NS 8141-2:2013", "Vibration and shock - Guideline limit values for construction work, open-pit and pit mining and traffic - Part 2: Effects of vibration on construction works from construction activities other than blasting, and from traffic". Norway, 2013, 20 pp. (In Norwegian).

44. Norwegian Standard: "NS 9431:2011”, “Classification of Waste”. Norway, 2011, 24 pp. (In Norwegian).

45. Interstate standard "GOST 32495-2013. Aggregates, fines and its mixtures made from recycled reinforced and non-reinforced concrete. Specifications”. Moscow, Russia, 2015, $13 \mathrm{pp}$.

46. Norwegian Environment agency "Faktaark M-14/2003 Disposal of concrete and brick waste", 2 pp. (In Norwegian).

47. Government Decree on the Recovery of Certain Wastes in Earth Construction (843/2017) Legislation in force - FINLEX ${ }^{\circledR}$. [Online]. [Accessed 8 February 2021]. Available from: 843/2017 English - Translations of Finnish acts and decrees - FINLEX.

48. Land Use and Building Act 132/1999 - Legislation in force - FINLEX ®. [online]. $\begin{array}{lllll}\text { [Accessed } & 23 & \text { February } & \text { 2020]. Available from: }\end{array}$ https://www.finlex.fi/fi/laki/alkup/1999/19990132 (In Finish).

49. Ympäriston-suojelu Ympäristöasioiden hallinta kiviainestuotannossa Suomen ympäristökeskus Paras käyttökelpoinen tekniikka (BAT). In : ISBN 978-952-11-3810-2 (In Finish). 
50. SINTEF Byggforsk: “241.070” “Avfallshåndtering I byggesaker. Planlegging og dokumentasjon". Oslo, Norway, 2017. (In Nowegian).

51. SINTEF Byggforsk: "700.802", "Miljøkartlegging og miljøanering ved riving og ombygging”. Oslo, Norway, 2018, 19 pp. (In Norwegian).

52. Nation Standards of Russia: "SP 325.1325800.2017", "Building and construction. Rules for the production of demolition and recycling". Moscow, Russia, 2017, 56 pp.

53. Nation Standards of Russia: "Construction regulation 51.13330.2011", "Noise protection and rooms acoustics". Moscow, Russia, 2011, 33 pp.

54. NOSTROY: "No 2.33.53-2011", "Demolition (dismantling) of buildings and structures". Moscow, Russia, 2012, 38 pp.

55. European Panel Federation (EPF), 2016. [online]. [Accessed 16 February 2021]. Available from: http://www.fir-recycling.com/.

56. Baumann H \& Tillman A: "The hitch hiker's guide to LCA", Studentlitteratur, Dimograf, Poland, 2015.

57. Broadbent C: "Steel's recyclability: demonstrating the benefits of recycling steel to achieve a circular economy". The International Journal of Life Cycle Assessment, Vol 21, No 11, 2016, pp. 1658-1665.

58. Knoeri C, Sanyé-Mengual E \& Althaus H: "Comparative LCA of recycled and Conventional concrete for structural applications". The International Journal of Life Cycle Assessment, Vol 18, No 5, 2013, pp. 909-918.

59. Mah C M, Fujiwara T \& Ho C S: "Concrete Waste Management Decision Analysis Based On Life Cycle Assessment". Chemical Engineering Transaction, Vol. 56, pp. 25-30. DOI:10.3303/CET1756005.

60. European Commission: "Council Directive 1999/31/EC of 26 April 1999 on the landfill of waste". Official Journal of the European Union, Vol 182, No 1, 1999.

61. Norwegian Environment agency "Betong- og teglavfall". [Online]. [Accessed 16 February 2021]. Available from: https://miljostatus.miljodirektoratet.no/tema/avfall/avfallstyper/betong--og-teglavfall/ (In Norwegian).

62. Norwegian Standard: "NS-EN 12620:2002+A1:2008+NA:2016", "Aggregates for Concrete". Norway, 2016, 68 pp.

63. Norwegian Standard: "NS-EN 206:2013+A1:2016+NA:2020", "Concrete - Specification, performance, production and conformity". Norway, 2020, $120 \mathrm{pp}$.

64. Nation Standards of Russia: "GOST 26633-2015", "Heavy-weight and sand concrete. Specifications". Moscow, Russia, 2016, 16 pp.

65. Fedotkina O, Gorbashko E \& Vatolkina E: "Circular Economy in Russia: Drivers and Barriers for Waste Management Development”. Sustainability, Vol 11, No 5837, 2019. 